\title{
LINKING ETHICAL STANDARDS FOR HEALTHCARE PROFESSIONALS WITH INDIAN CULTURAL VALUES
}

\section{---Ethical standard-setting rooted in cultural values for healthcare professionals in India.}

\author{
Phathara-On Wesarat', Jaya Mathew² \\ 1. Prince of Songkla University (Pattani Campus), Thailand \\ 2. K J Somaiya Institute of Management, Mumbai, India
}

Correspondence: jayamathew@somaiya.edu

\begin{abstract}
Ethical standards of healthcare sector are important to the lives of people because healthcare is a profession that impacts the lives of people, their families and society. Healthcare professionals are inevitably involved in ethical decision-making in their working lives and address a conflict regarding competing values such as personal, organizational, professional, and community values. India is a country in South Asia where people are diverse in ethnicity, religion, and culture. So, revealing commonly accepted ethical standards for resolving ethical conflicts for healthcare professionals becomes more relevant for India. However, the research on this issue is limited. Therefore, the purpose of this paper is to reveal the link between ethical standards for healthcare professionals in general and Indian cultural values such as Dharma, Nishkama Karma and Jnana.
\end{abstract}

This paper used a scoping review to screen the relevant articles which were selected from the Scopus and Google Scholar databases. The keywords used for searching the research articles were "ethical standard", "ethics", "healthcare ethics", and "Indian cultural values". Then, the constructs of healthcare ethics were identified and the relevant ethical standards for each construct were not only evaluated based on the two key theoretical viewpoints namely deontology and teleology, but also justified by Indian cultural values.

\section{KEYWORDS}

Ethical Standard, Ethics, Healthcare Ethics, Healthcare Professional, Indian Cultural Values

\section{INTRODUCTION}

Healthcare organizations should provide patients with reasonable care and serve their interests [1] and this can be possible only if healthcare professionals serve selflessly. However, in practice, they may be confused with "right" and "wrong" behavior, and examples of healthcare professionals' difficulties in ethical decision-making exist in many regions. [2] Attack of Ebola virus disease (EVD) in the West African countries in 2016 and Nipah Virus outbreak in South India in 2019 emphasized the need for preparedness 
and readiness on the part of healthcare professionals for incident management regardless of types of contingencies. [3] Moreover, healthcare professionals seemed to face frustration on ethical considerations as maintaining positive outcomes (e.g., intensive patient care) pester them despite limited staffing and inadequate equipment. [2]

In India, there is the code of medical ethics regulations 2002 that is also called the Indian Medical Council (Professional conduct, Etiquette and Ethics) Regulations 2002. [4] But ethical standards sometimes are neglected by medical practitioners. Recently, there has been an increasing concern of healthcare ethics, especially during the Covid19 pandemic. Though the case fatality rate has come down to $1.43 \%$ as of February 2021, [5] ethical questions such as distributing limited medical resources among patients with Covid-19 and allocating limited medical resources among patients with Covid-19 and non-Covid patients subsist. [6] Moreover, in spite of having government policies on the healthcare system, inequality does exist as in the case of unorganized laborers. Yet, government policies can influence healthcare professionals' ethical decision-making and ethical behavior.

To avoid healthcare professionals' frustration on ethical decision-making, specific ethical standards are required. Though ethical standards that are acceptable to all Indian citizens are rarely found in the related literature, Okpara, 2014 stated that culture significantly impacted managers' ethical attitudes, affecting their ethical behavior [7] and a study conducted by Chao, Li \& Chen, 2016 has emphasized individuals' ethical decision-making influenced by local cultural norms. [8] This paper aims to reveal the link between ethical standards for healthcare professionals in general (i.e., international/universal ethical standards) and Indian cultural values including dharma (the belief in responsibility towards others, e.g., sharing resources with as many people as possible is viewed as the noble ideal of human life), [9] jnana (knowledge is a basis for human being), [10] and nishkama karma (an individual's selfless action without fear of the results). [11] The congruence of ethical standards for healthcare professionals and Indian cultural values may have a positive impact on their ethical decision-making and ethical behavior.

\section{A SCOPING REVIEW}

This paper adopted a scoping review as it is used to "describe an existing evidence base and to provide the first step towards conducting a systematic review." [12] The relevant studies from the Scopus and Google Scholar have been revealed. Ethics refers to "a systematic approach to moral judgments based on reason, analysis, synthesis, and reflection of one's environment." [13] Principles of ethics are used to judge what is right (good) and wrong (bad) conduct. [14] During the Covid-19 pandemic, many hospitals stopped their non-Covid service, and they paid more attention to serve Covid-19 patients. [15] The inability to equally respond to the needs of all groups of patients resulted in frustration among healthcare professionals.

Whereas there are various theoretical viewpoints of ethics, this paper focused on two key theoretical perspectives of ethics comprising deontological theory and teleological theory that have been widely discussed by prior studies. [14] Deontological theory focuses on the means, while teleological theory emphasizes the ends. [16] Both deontological and teleological theories can be applied for developing the ethical decision-making (EDM) framework. In this paper these two theoretical perspectives are used to justify ethical standards for healthcare professionals in India.

\section{DEONTOLOGICAL THEORY}

According to deontological theory, the right action must comply with moral duties or rules. [17] From a motivational perspective, the right action means the action that has been derived from a person's motivation to do his or her duty. [18] It can be said that the right action is judged by the action itself and a person's intention to morally act. [19] Therefore, individuals are required to act in line with the rule or code of conduct without considering the impact of their actions. [20] Likewise, healthcare professionals are also expected to perform the duty that is at the heart of healthcare ethics.

\section{TELEOLOGICAL THEORY}

Teleological theory focuses on the result of an action. [14] According to this school, the right action is judged by its outcome (e.g., the greatest good to the greatest number of people who are affected by the action). [19] Accordingly, healthcare professionals should be able to effectively assess the outcome of their conduct. [19] So 
teleological theory is useful to enhance the healthcare system to accomplish healthcare equality in India where citizens are varied in many respects.

Basically, healthcare knowledge is used to evaluate the outcome of a specific action. [21] To evaluate ethical behavior, healthcare knowledge as well as ethical standard should be considered. The assessment of healthcare professionals' ethical behavior needs to explore how well they provide a good service to the maximum number of citizens. [19]

\section{HEALTHCARE VALUES}

Ethical standards for healthcare professionals are derived from healthcare values. Since the goal of the healthcare sector is to promote the healthy lives of people, healthcare professionals must work for helping others and serving the benefit of society. [22] Healthcare professionals, to decide and act ethically, need to be involved in two conditions; firstly, perceive what the core values of their profession are and secondly, to have the ability to act in accordance with the profession's values. [23]

In the healthcare sector, the goals of the physicians and managers may be conflicting. Physician's goal to treat individual patients with the best method [24] is consistent with deontological theory, which focuses on moral duties. [17] On the other hand, a manager's goal to maximize the quality of healthcare services with a minimal cost to the population demonstrates congruence with teleological theory. [24][14] Even though healthcare ethical values in India seem to be adopted from the Western society, ethical issues in healthcare in the context of India have been published by the journals such as Indian Journal of Medical Sciences [15], and Indian Journal of Medical Ethics. [25]

\section{CULTURAL DIMENSION OF ETHICS}

The cultural dimension of ethics should be considered to build trust among people in a specific area [14] and culture is viewed as an important determinant of ethical attitude and behavior among people in society. [13] Based on Hofstede's categorization, India is labelled as a collectivistic society where people put a high value on collective gain instead of individual interest. [26] Indian value perceives an individual's commitment to one's group as ethical behavior. [26] Therefore, Indian tradition emphasized holistic view by balancing between individual and societal interests. [26] The root of ethics is associated with Indian cultural values: dharma (obligation of moral duty and responsibility towards others), nishkama karma (motivation to work without fear of the results), and jnana (knowledge orientation or wisdom). [27]

The survival of human society, its stability and growth depend upon the right conduct of individuals and the Vedas and Dharmasastras [27], which are meant to regulate the life of the community command that every individual must perform certain deeds in conformity with divine laws. [28] Accordingly, the Indian tradition of dharma refers to all the duties one should perform and all the virtues one should practice. Karma refers to action [29] and nishkama karma is duty without desire. So, no one should be motivated by the results of one's actions. [30] The practice of jnana (wisdom) helps one to realize the temporary nature of maya (world). [31] Thus, the Indian cultural values aim at improving human conditions to a higher level of being.

\section{ETHICAL STANDARDS FOR HEALTHCARE PROFESSIONALS AND INDIAN CULTURAL VALUES}

This section begins with the operational definitions and discusses the link between healthcare professionals and Indian cultural values. Definitions used in this paper are as below.

"Healthcare professional" refers to the worker who works for healthcare services, including health professional (e.g., nurse and physician), allied health professional (e.g., social worker), and healthcare manager. [32]

"Ethics" is defined as the principles and moral judgments of what is right and wrong. [33]

"Ethical standard" is defined as a set of acceptable actions derived from moral philosophies. [33]

"Ethical decision-making" is the way in which a decisionmaker considers ethical criteria for choosing the right choice over other alternative choices. [34]

"Cultural values" refers to a set of values or beliefs shared by a group's members that distinguish one group from another. [35]

This paper categorized the constructs of healthcare ethics and identified ethical standards for each construct. The ethical standards for each construct were not only 
evaluated based on two key theoretical viewpoints, namely deontology and teleology, but they were also justified by Indian cultural values.

Ethical decision-making is derived from certain ethical standards that are good for all people regardless of ethnicity, religion, or class of the people. [36] Ethical standards for healthcare professionals could be developed based on a combination of professional values, moral philosophies, religions, and cultural values. [36]. In line with multicultural medical ethics, all groups of Indian citizens should be treated based on a core principle of ethics that values diversity and respects humaneness. [23] There are several principles of ethics that are applicable to healthcare professionals in India. Considering the demographic diversity in the country, India requires ethical standards which are acceptable to all groups of people. This paper, however, presented preliminary review on ethical standards and Indian cultural values. India is predominantly a Hindu country with $80 \%$ of its population [13]. Therefore, this paper discussed mainly based on predominant cultural values of India. They may not be generalizable to the population of the whole country.
In this paper, healthcare ethics emphasizes four constructs that are autonomy, non-maleficence, beneficence, and justice, as follows.

1) Autonomy; protecting the rights and dignity of patients. [37]

2) Non-maleficence; avoidance and precaution of harm to human beings. [38]

3) Beneficence; acting with the intention of benefitting others. [38]

4) Justice; maintaining fair decision-making procedures and outcomes. [39]

Based on four constructs of healthcare ethics, ethical standards for healthcare professionals were identified. Then, checked whether the identified ethical standards were consistent with theoretical viewpoints (deontological theory and teleological theory) and Indian cultural values.

Table 1 below establishes a link between the construct of healthcare ethics, ethical standard, theoretical viewpoints, and Indian cultural values.

TABLE 1

\begin{tabular}{|c|c|c|c|c|c|}
\hline \multirow{2}{*}{$\begin{array}{l}\text { CONSTRUCT } \\
\text { OF } \\
\text { HEALTHCAR } \\
\text { E ETHICS }\end{array}$} & \multirow{2}{*}{$\begin{array}{l}\text { ETHICAL } \\
\text { STANDARD }\end{array}$} & \multirow{2}{*}{$\begin{array}{l}\text { RESEARCHE } \\
\text { R }\end{array}$} & \multicolumn{2}{|c|}{ THEORETICAL VIEWPOINTS } & \multirow{2}{*}{$\begin{array}{l}\text { INDIAN } \\
\text { CULTURAL } \\
\text { VALUES }\end{array}$} \\
\hline & & & $\begin{array}{l}\text { DEONTOLOGI } \\
\text { CAL THEORY }\end{array}$ & $\begin{array}{l}\text { TELEOLOGIC } \\
\text { AL THEORY }\end{array}$ & \\
\hline \multirow[t]{4}{*}{ Autonomy } & $\begin{array}{l}\text { Protection of } \\
\text { patients' privacy } \\
\text { (e.g., } \\
\text { considering } \\
\text { privacy in } \\
\text { personal health } \\
\text { monitoring) }\end{array}$ & $\begin{array}{l}\text { Loi, Christen, } \\
\text { Kleine and } \\
\text { Weber (2019) } \\
\text { [40] } \\
\text { Nordgren } \\
\text { (2013) [41] }\end{array}$ & $\sqrt{ }$ & & dharma \\
\hline & & $\begin{array}{l}\text { Palm (2013) } \\
{[42]}\end{array}$ & & & \\
\hline & $\begin{array}{l}\text { Refusing to use } \\
\text { unethical } \\
\text { medical } \\
\text { procedures }\end{array}$ & $\begin{array}{l}\text { Zydziunaite } \\
\text { et al. (2015) } \\
\text { [1] }\end{array}$ & $\sqrt{ }$ & & dharma \\
\hline & $\begin{array}{l}\text { Sustaining } \\
\text { psychological } \\
\text { contract with } \\
\text { patients (e.g., }\end{array}$ & $\begin{array}{l}\text { Chang, Wu } \\
\text { and Du } \\
\text { (2020) [43] }\end{array}$ & $\sqrt{ }$ & & dharma \\
\hline
\end{tabular}




\begin{tabular}{|c|c|c|c|c|c|}
\hline \multirow{2}{*}{$\begin{array}{l}\text { CONSTRUCT } \\
\text { OF } \\
\text { HEALTHCAR } \\
\text { E ETHICS }\end{array}$} & \multirow{2}{*}{$\begin{array}{l}\text { ETHICAL } \\
\text { STANDARD }\end{array}$} & \multirow{2}{*}{$\begin{array}{l}\text { RESEARCHE } \\
R\end{array}$} & \multicolumn{2}{|c|}{ THEORETICAL VIEWPOINTS } & \multirow{2}{*}{$\begin{array}{l}\text { INDIAN } \\
\text { CULTURAL } \\
\text { VALUES }\end{array}$} \\
\hline & & & $\begin{array}{l}\text { DEONTOLOGI } \\
\text { CAL THEORY }\end{array}$ & $\begin{array}{l}\text { TELEOLOGIC } \\
\text { AL THEORY }\end{array}$ & \\
\hline & $\begin{array}{l}\text { building good } \\
\text { communication } \\
\text { between } \\
\text { healthcare } \\
\text { professional and } \\
\text { patient) }\end{array}$ & $\begin{array}{l}\text { Van Zaalen, } \\
\text { McDonnell, } \\
\text { Mikotajczyk, } \\
\text { Buttigieg, } \\
\text { Requena } \\
\text { and } \\
\text { Holtkamp } \\
\text { (2018) [44] }\end{array}$ & & & \\
\hline & $\begin{array}{l}\text { Making patients } \\
\text { to fully } \\
\text { understand both } \\
\text { the benefits and } \\
\text { risks resulted } \\
\text { from medical } \\
\text { care }\end{array}$ & $\begin{array}{l}\text { Mackert, } \\
\text { Guadagno, } \\
\text { Mabry and } \\
\text { Chilek (2013) } \\
\text { [45] }\end{array}$ & $\sqrt{ }$ & & dharma \\
\hline & $\begin{array}{l}\text { Informing } \\
\text { patients about } \\
\text { costs and } \\
\text { benefits of a } \\
\text { treatment }\end{array}$ & $\begin{array}{l}\text { Fornaciari } \\
\text { and Callens } \\
(2012)[46]\end{array}$ & $\sqrt{ }$ & & dharma \\
\hline & $\begin{array}{l}\text { Informing } \\
\text { patients about } \\
\text { the options } \\
\text { available }\end{array}$ & $\begin{array}{l}\text { Bowden and } \\
\text { Smits (2012) } \\
{[47]}\end{array}$ & $\sqrt{ }$ & & dharma \\
\hline & $\begin{array}{l}\text { Protecting the } \\
\text { rights of patients } \\
\text { to choose } \\
\text { between } \\
\text { expensive or } \\
\text { lower cost } \\
\text { treatments }\end{array}$ & $\begin{array}{l}\text { Kantabutra } \\
\text { (2011) [48] }\end{array}$ & $\sqrt{ }$ & & dharma \\
\hline & $\begin{array}{l}\text { Giving } \\
\text { healthcare } \\
\text { services to } \\
\text { everyone } \\
\text { regardless of } \\
\text { age and severity } \\
\text { of disease }\end{array}$ & $\begin{array}{l}\text { Hosseini } \\
\text { (2018) [49] }\end{array}$ & $\sqrt{ }$ & & dharma \\
\hline \multirow[t]{2}{*}{$\begin{array}{l}\text { Non- } \\
\text { maleficence }\end{array}$} & $\begin{array}{l}\text { Minimizing risks } \\
\text { to patients }\end{array}$ & $\begin{array}{l}\text { Loi et al. } \\
\text { (2019) [40] }\end{array}$ & & $\sqrt{ }$ & jnana \\
\hline & $\begin{array}{l}\text { Serving patients } \\
\text { whose condition }\end{array}$ & $\begin{array}{l}\text { Geale (2012) } \\
\text { [33] }\end{array}$ & $\sqrt{ }$ & & $\begin{array}{l}\text { nishkama } \\
\text { karma }\end{array}$ \\
\hline
\end{tabular}




\begin{tabular}{|c|c|c|c|c|c|}
\hline \multirow{3}{*}{$\begin{array}{l}\text { CONSTRUCT } \\
\text { OF } \\
\text { HEALTHCAR } \\
\text { E ETHICS }\end{array}$} & \multirow{2}{*}{$\begin{array}{l}\text { ETHICAL } \\
\text { STANDARD }\end{array}$} & \multirow{2}{*}{$\begin{array}{l}\text { RESEARCHE } \\
R\end{array}$} & \multicolumn{2}{|c|}{ THEORETICAL VIEWPOINTS } & \multirow{2}{*}{$\begin{array}{l}\text { INDIAN } \\
\text { CULTURAL } \\
\text { VALUES }\end{array}$} \\
\hline & & & $\begin{array}{l}\text { DEONTOLOGI } \\
\text { CAL THEORY }\end{array}$ & $\begin{array}{l}\text { TELEOLOGIC } \\
\text { AL THEORY }\end{array}$ & \\
\hline & $\begin{array}{l}\text { requires } \\
\text { immediate } \\
\text { attention first }\end{array}$ & & & & \\
\hline \multirow[t]{6}{*}{ Beneficence } & $\begin{array}{l}\text { Acting for the } \\
\text { best interest of } \\
\text { individual } \\
\text { patients }\end{array}$ & $\begin{array}{l}\text { Loi et al. } \\
\text { (2019) [40] }\end{array}$ & & $\sqrt{ }$ & jnana \\
\hline & $\begin{array}{l}\text { Considering } \\
\text { cost-benefit } \\
\text { analysis in } \\
\text { providing } \\
\text { healthcare } \\
\text { services }\end{array}$ & $\begin{array}{l}\text { Parhizgar et } \\
\text { al. (2009) [22] }\end{array}$ & & $\sqrt{ }$ & jnana \\
\hline & $\begin{array}{l}\text { Considering } \\
\text { cost- } \\
\text { effectiveness } \\
\text { analysis in } \\
\text { providing } \\
\text { healthcare } \\
\text { services }\end{array}$ & $\begin{array}{l}\text { Parhizgar et } \\
\text { al. (2009) [22] } \\
\text { Clarke and } \\
\text { Weale (2012) } \\
\text { [50] }\end{array}$ & & $\sqrt{ }$ & jnana \\
\hline & $\begin{array}{l}\text { Concerning the } \\
\text { quality-of-care } \\
\text { delivery }\end{array}$ & $\begin{array}{l}\text { Carney } \\
(2011) \text { [51] }\end{array}$ & & $\sqrt{ }$ & jnana \\
\hline & & $\begin{array}{l}\text { Agnihothri } \\
\text { and } \\
\text { Agnihothri } \\
\text { (2018) [52] }\end{array}$ & & & \\
\hline & $\begin{array}{l}\text { Providing } \\
\text { patients with } \\
\text { healthcare } \\
\text { services that are } \\
\text { consistent with } \\
\text { current medical } \\
\text { knowledge }\end{array}$ & $\begin{array}{l}\text { Medhekar, } \\
\text { Wong and } \\
\text { Hall (2020) } \\
{[53]}\end{array}$ & & $\sqrt{ }$ & jnana \\
\hline \multirow[t]{2}{*}{ Justice } & $\begin{array}{l}\text { Allocation of the } \\
\text { resources to the } \\
\text { greatest number } \\
\text { of patients }\end{array}$ & $\begin{array}{l}\text { Loi et al. } \\
\begin{array}{l}\text { (2019) [41] } \\
\text { Geale (2012) } \\
\text { [33] }\end{array}\end{array}$ & & $\sqrt{ }$ & jnana \\
\hline & $\begin{array}{l}\text { Assessment of a } \\
\text { comparative }\end{array}$ & $\begin{array}{l}\text { Simonen, } \\
\text { Viitanen and }\end{array}$ & & $\sqrt{ }$ & jnana \\
\hline
\end{tabular}




\begin{tabular}{|c|c|c|c|c|c|}
\hline \multirow{3}{*}{$\begin{array}{l}\text { CONSTRUCT } \\
\text { OF } \\
\text { HEALTHCAR } \\
\text { E ETHICS }\end{array}$} & \multirow{2}{*}{$\begin{array}{l}\text { ETHICAL } \\
\text { STANDARD }\end{array}$} & \multirow{2}{*}{$\begin{array}{l}\text { RESEARCHE } \\
\mathbf{R}\end{array}$} & \multicolumn{2}{|c|}{ THEORETICAL VIEWPOINTS } & \multirow{2}{*}{$\begin{array}{l}\text { INDIAN } \\
\text { CULTURAL } \\
\text { VALUES }\end{array}$} \\
\hline & & & $\begin{array}{l}\text { DEONTOLOGI } \\
\text { CAL THEORY }\end{array}$ & $\begin{array}{l}\text { TELEOLOGIC } \\
\text { AL THEORY }\end{array}$ & \\
\hline & $\begin{array}{l}\text { effectiveness } \\
\text { data to } \\
\text { compromise the } \\
\text { rights of a single } \\
\text { patient and the } \\
\text { needs of society } \\
\text { as a whole }\end{array}$ & $\begin{array}{l}\text { Blom (2012) } \\
\text { [54] }\end{array}$ & & & \\
\hline
\end{tabular}

The table 1 showed the congruence between ethical standards for healthcare professionals and Indian cultural values. The ethical standards for healthcare professionals, in general, are more likely to be associated with Indian cultural values, namely "dharma" and "jnana", compared to "nishkama karma".

The term "dharma" focuses on an individual's duty and responsibility towards others. It can be said that it is consistent with deontological theory since it focuses on a person's duty to perform rather than the result of a person's action. [20] Therefore, international ethical standards for healthcare professionals based on the principles of the deontological theory apply to healthcare professionals in India too. Additionally, "jnana" i.e., knowledge orientation emphasizes the essence of the teleological theory and encourages individuals to realize the result of an action to make the best ethical decision possible. [27] [31] However, nishkama karma concerned with duty without desire [30] has received less attention from the theoretical viewpoints of ethics.

Whereas the table 1 showed only four constructs of healthcare ethics (such as autonomy, non-maleficence, beneficence, and justice), its limitation is that these constructs consider only few factors when making an ethical decision. Henceforth, future research should develop a comprehensive model that will be more useful for healthcare professionals.

Additionally, although this paper found that link between ethical standards and Indian cultural values, the extent to which individuals are able to practically carry out ethical standards may depend on their educational level. The past study argues that the level of education affects an individual's ethical decision-making. [55] As educational level is the determinant of a person's moral reasoning [55], educational institutions in India should include ethics in the healthcare curriculum. They probably promote healthcare ethics through teaching and learning process in order to produce graduates with the capabilities to understand and interpret ethical standards into practices.

\section{CONCLUSION AND IMPLICATIONS}

On the one hand, lack of resources in the healthcare sector seems to be problematic for healthcare professionals in their ethical decision and behavior making. [2] On the other hand, cultural values influence healthcare professionals' ethical behavior. Individuals seemed to accept ethical standards that are not only based on universal moral values but also concerned with values shared among people in the society (e.g., social, cultural, religious, and occupational features). [50] By reviewing the literature, it has been found that there is harmony between ethical standards for healthcare professionals and Indian cultural values. This means healthcare professionals in India might confidently follow international ethical standards if they are consistent with Indian cultural values.

Future research on ethical standards for healthcare professionals in India should investigate the priority-setting of ethical standards to establish structured ethical decisionmaking procedures that will enable healthcare professionals to behave ethically because the degree to which cultural values influence ethical standards differs among countries. However, this paper is based on a scoping review in preparation for further study. It may lack a potential to be generalizable. 


\section{References}

1. Zydziunaite, V., Lepaite, D., Åstedt-Kurki, P. \& Suominen, T. (2015). Head nurses' decision-making when managing ethical dilemmas. Baltic Journal of Management, 10(2), 166-187.

2. Petrosillo, N. \& Čivljak, R. (2019). Ebola virus disease: A lesson in science and ethics. Ethics and Integrity in Health and Life Sciences Research, 4, 33-44.

3. Thomas, B., Chandran, P., Lilabi, M.P., George, B., Sivakumar, C.P., Jayadev, V.K., Bindu, V., Rajasi, R.S., Vijayan, B., Mohandas, A. \& Hafeez, N. (2019). Nipah Virus infection in Kozhikode, Kerala, South India, in 2018: Epidemiology of an outbreak of an emerging disease. Indian Journal of Community Medicine, 44(4), 383-387.

4. National Medical Commission (2002). Code of Medical Ethics Regulations 2002. Retrieved September 11, 2021, from https://www.nmc.org.in/rulesregulations/code-of-medical-ethics-regulations-2002/

5. Ministry of Health and Family Welfare, Government of India (2021). For information on Covid-19 Vaccine. Retrieved February 15, 2021, from https://mohfw.gov.in.

6. Hebbar, P., Sudha, A., Dsouza, V., Chilgod, L. \& Amin, A. (2021). Healthcare delivery in India amid the Covid19 pandemic: Challenges and opportunities.

Retrieved January 3, 2021, from

https://doi.org/10.20529/IJME.2020.064

7. Okpara, J.O. (2014). The effects of national culture on managers' attitudes toward business ethics: Implications for organizational change. Journal of Accounting \& Organizational Change, 10(2), 174-189.

8. Chao, M.C., Li, F. \& Chen, H. (2016). Perceived ethicality of moral choice: The impact of ethics codes, moral development, and relativism. Nankai Business Review International, 7(2), 258-279.

9. Kanagasabapathi, P. (2007). Ethics and values in Indian economy and business. International Journal of Social Economics, 34(9), 577-585.

10. Singh, V. (2019). Relationship between the spiritual and the secular: Vivekananda, Gandhi and Radhakrishnan. Studies in Indian Politics, 7(1), 56-69.

11. Tripathi, R. \& Kumar, A. (2020). Humanistic leadership in the Tata group: The strategy in personal values, organisational strategy and national cultural ethos. Cross Cultural \& Strategic Management, 27(4), 607626.
12. Reece, R., Bray, I., Sinnett, D., Hayward, R. \& Martin, F. (2021). Exposure to green space and prevention of anxiety and depression among young people in urban settings: A global scoping review. Retrieved September 10, 2021, from https://doi.org/10.1108/JPMH-02-2021-0030

13. Berger, R. \& Herstein, R. (2014). The evolution of business ethics in India. International Journal of Social Economics, 41 (11), 1073-1086.

14. Goswami, M., Agrawal, R.K. \& Goswami, A.K. (2020). Ethical leadership in organizations: Evidence from the field. Retrieved January 2, 2021, from https://doi.org/10.1108/IJOES-04-2020-0048

15. Gulia, A. \& Salins, N. (2020). Ethics-based decisionmaking in a Covid-19 pandemic crisis. Indian Journal of Medical Sciences, 72(2), 39-40.

16. Kang, B.G., Edum-Fotwe, F., Price, A. \& Thorpe, T. (2014). The application of causality to construction business ethics. Social Responsibility Journal, 10(3), 550-568.

17. Francalanza, C. \& Buttigieg, E. (2016). Maltese certified public accountants and whistleblowing: Traits, influences and propensity. Journal of Applied Accounting Research, 17(3), 262-284.

18. Barlaup, K., Drønen, H.I. \& Stuart, I. (2009). Restoring trust in auditing: Ethical discernment and the Adelphia scandal. Managerial Auditing Journal, 24(2), 183-203.

19. Ertz, M., Karakas, F., Stapenhurst, F., Draman, R., Sarigöllü, E. \& Jo, M.S. (2020). How misconduct in business contributes to understanding the supply side of corruption in international business. Critical Perspectives on International Business, 16(3), 209-231.

20. Shaikh, J.M. \& Talha, M. (2003). Credibility and expectation gap in reporting on uncertainties. Managerial Auditing Journal, 18(6/7), 517-529.

21. Parhizgar, F.F., Parhizgar, S.S. \& Parhizgar, K.D. (2009). Analysis of multicultural meta-ethical clinical perceptions concerning life and death of patients. Competitiveness Review: An International Business Journal, 19(5), 409-422.

22. Kearney, C., Dunne, P. \& Wales, W.J. (2020). Entrepreneurial orientation and burnout among healthcare professionals. Journal of Health Organization and Management, 34(1), 16-22.

23. Gadolin, C., Andersson, T., Eriksson, E. \& Hellström, A. (2020). Providing healthcare through "value shops": Impact on professional fulfillment for physicians and 
nurses. International Journal of Health Governance, 25(2), 127-136.

24. Bitter, J., Van Veen-Berkx, E., Gooszen, H.G. \& Van Amelsvoort, P. (2013). Multidisciplinary teamwork is an important issue to healthcare professionals. Team Performance Management, 19(5/6), 263-278.

25. Prabhu, G. (2021). Narratives of endurance and the ethics of listening. Indian Journal of Medical Ethics, Retrieved September 11, 2021, from https://doi.org/10.20529/IJME.2021.034

26. Kaur, J. \& Sharma, S.K. (2016). Examining relationships among corporate ethical values, commitment, and turnover intentions. South Asian Journal of Global Business Research, 5(1), 32-52.

27. Wezler, A. (2004). Dharma in the Veda and the Dharmasastras. Journal of Indian Philosophy, 32(5/6), 629-654.

28. Creel, A.B. (1972). Dharma as an ethical category relating to freedom and responsibility. Philosophy East and West, 22(2), 155-168.

29. Burley, M. (2014). Karma, morality, and evil. Philosophy Compass, $9(6), 415-430$.

30. Hutchinson, J.F. \& Sharp, R. (2008). Karma, reincarnation, and medicine: Hindu perspectives on biomedical research. Genomic Medicine, 2(3-4), 107111.

31. Rao, K.R. (2012). Psychology in Indian tradition. Psychological Studies, 57, 323-330.

32. Mansfield, E., Sandercock, J., Dowedoff, P., Martel, S., Marcinow, M., Shulman, R., Parks, S., Peters, M., Versloot, J., Kerr, J. \& Zenlea, I. (2020). Implementing integrated care pilot projects in hospital settings - An exploration of disruptive practices. Retrieved January 24, 2021, from https://doi.org/10.1108/JICA-12-20190051

33. Geale, S.K. (2012). The ethics of disaster management. Disaster Prevention and Management, 21 (4), 445-462.

34. Whittier, N.C., Williams, S. \& Dewett, T.C. (2006). Evaluating ethical decision-making models: A review and application. Society and Business Review, 1 (3), 235-247.

35. Stone, D.L., Johnson, R.D., Stone-Romeo, E.F. \& Hertman, M. (2005). A comparative study of HispanicAmerican and Anglo-American cultural values and job choice preferences. Management Research, 4(1), 7-21.

36. Dunn, P. \& Sainty, B. (2019). Professionalism in accounting: A five-factor model of ethical decisionmaking. Social Responsibility Journal, 16(2), 255-269.

37. Usher, R. \& Stapleton, T. (2018). Overview of the assisted decision-making (capacity) act (2015): Implications and opportunities for occupational therapy. Irish Journal of Occupational Therapy, 46(2), 130-140.

38. Ryan, M. \& Stahl, B.C. (2020). Artificial intelligence ethics guidelines for developers and users: Clarifying their content and normative implications. Retrieved February 1 1, 2021, from https://doi.org/10.1 108/JICES12-2019-0138

39. De Clercq, D., Haq, I.U. \& Azeem, M.U. (2020). Unpacking the relationship between procedural justice and job performance. Retrieved February 12, 2021, from https://doi.org/10.1108/MD-09-2019-1211

40. Loi, M., Christen, M., Kleine, N. \& Weber, K. (2019). Cybersecurity in health-disentangling value tensions. Journal of Information, Communication and Ethics in Society, 17(2), 229-245.

41. Nordgren, A. (2013). Personal health monitoring: Ethical considerations for stakeholders. Journal of Information, Communication and Ethics in Society, $11(3), 156-173$.

42. Palm, E. (2013). An interactive ethical assessment of surveillance-capable software within the home-help service sector. Journal of Information, Communication and Ethics inSociety, $11(1), 43-68$.

43. Chang, P., Wu, T. \& Du, J. (2020). Psychological contract violation and patient's antisocial behaviour: A moderated mediation model of patient trust and doctor-patient communication. International Journal of Conflict Management, 31 (4), 647-664.

44. Van Zaalen, Y., McDonnell, M., Mikołajczyk, B., Buttigieg, S., Requena, M.C. \& Holtkamp, F. (2018). Technology implementation in delivery of healthcare to older people: How can the least voiced in society be heard? Journal of Enabling Technologies, 12(2), 7690.

45. Mackert, M., Guadagno, M., Mabry, A. \& Chilek, L. (2013). DTC drug advertising ethics: Laboratory for medical marketing. International Journal of Pharmaceutical and Healthcare Marketing, 7(4), 374390. 
46. Fornaciari, D. \& Callens, S. (2012). Competition rules and health care players: Principles and consequences. International Journal of Health Care Quality Assurance, 25(5), 379-386.

47. Bowden, D.E. \& Smits, S.J. (2012). Managing in the context of healthcare's escalating technology and evolving culture. Journal of Health Organization and Management, 26(2), 149-157.

48. Kantabutra, S. (2011). Sustainable leadership in a Thai healthcare services provider. International Journal of Health Care Quality Assurance, 24(1), 67-80.

49. Hosseini, H. (2018). Ethical dilemmas in the practice of nursing. International Journal of Ethics and Systems, 34(2), 250-263.

50. Clarke, S. \& Weale, A. (2012). Social values in health priority setting: A conceptual framework. Journal of Health Organization and Management, 26(3), 293316.

51. Carney, M. (2011). Influence of organizational culture on quality healthcare delivery. International Journal of Health Care Quality Assurance, 24(7), 523-539.

52. Agnihothri, S. \& Agnihothri, R. (2018). Application of evidence-based management to chronic disease healthcare: A framework. Management Decision, 56(10), 2125-2147.

53. Medhekar, A., Wong, H.Y. \& Hall, J.E. (2020). Healthcare providers perspective on value in medical travel to India. Tourism Review, 75(4), 717-731.

54. Simonen, O., Viitanen, E. \& Blom, M. (2012). Factors relating to effectiveness data use in healthcare management. International Journal of Productivity and Performance Management, 61 (7), 752-764.

55. Goel, P. \& Misra, R. (2020). It's not inter-religiosity but intra-religiosity that really matters in attitude towards business ethics: Evidence from India. International Journal of Ethics and Systems, 36(2), 167-184. 